\title{
Penggunaan Ekstrak Bawang Putih (Allium sativum) Sebagai Bahan Alami Celup Puting terhadap Kualitas Mikrobiologis Susu Sapi Segar
}

\section{Thomas A. Nainoe ${ }^{\mathrm{a}}$, Paulus K. Tahuk ${ }^{\mathrm{b}}$ dan Theresia I. Purwantiningsih ${ }^{\mathrm{c}}$}

${ }^{a}$ Fakultas Pertanian, Universitas Timor, Kefamenanu, TTU-NTT, 85613, Indonesia, email :nainoealfin@gmail.com

${ }^{b}$ Fakultas Pertanian, Universitas Timor, Kefamenanu, TTU-NTT, 85613, Indonesia, email :paulklau@yahoo.co.id

${ }^{c}$ Fakultas Pertanian, Universitas Timor, Kefamenanu, TTU-NTT, 85613, Indonesia, email :theresiaicha@gmail.com

\section{Article Info}

\section{Article history:}

Received 15 Mei 2019

Received in revised form 20 Agustus 2019

Accepted 15 Oktober 2019

$\mathrm{DOI}:$

https://doi.org/10.32938/ja.v4i4.674

\section{Keywords:}

Ekstrak Bawang Putih

Celup Puting

Kualitas Susu

\section{Abstrak}

Penelitian ini dilaksanakan di Peternakan sapi perah Claretian Benlutu, Kecamatan Batu Putih, Kabupaten TTS selama satu bulan. Penelitian ini terdiri dari 2 tahap yaitu pencelupan puting selama 1 bulan dan tahap kedua pengujian sampel di laboratorium. Tujuan dari penelitian ini adalah mengetahui pengaruh penggunaan ekstrak bawang putih (Allium sativum) sebagai bahan alami celup puting terhadap kualitas mikrobiologis susu sapi segar. Dalam penelitian ini digunakan 16 puting susu dari 4 ekor ternak sapi perah. Rancangan percobaan yang digunakan adalah Rancangan Acak Lengkap dari 4 perlakuan dan 3 ulangan, dengan dengan perlakuannya adalah $\mathrm{R}_{0}=$ larutan antisep komersial sebagai kontrol, $\mathrm{R} 1=$ konsentrasi ekstrak bawang putih $20 \%$, R2 = konsentrasi ekstrak bawang putih $25 \%$ dan $\mathrm{R} 3=$ konsentrasi ekstrak bawang putih $30 \%$. Variabel yang diamati dalam penelitian ini adalah waktu reduktase dan total bakteri. Hasil penelitian menunjukkan bahwa penggunaan ekstrak bawang putih (Allium Sativum) memiliki efek yang sama dengan larutan antisep komersial dilihat dari waktu reduktase bakteri dan total bakteri $(\mathrm{P}>0,05)$. Hal ini karena bawang putih memiliki kandungan anti bakteri allicin yang mampu menghambat pertubuhan bakteri. Dapat disimpulkan bahwa ekstrak bawang putih memiliki kemampuan yang sama seperti larutan antisep komersial dalam menghambat bakteri penyebab mastitis pada puting susu sapi perah. Hasil uji mikrobiologis dari 2 variabel susu penggunaan ekstrak bawang putih dengan konsentrasi $20 \%$ sudah sangat optimal dalam penggunaan celup puting susu sapi perah selain menghambat bakteri juga menghemat biaya dalam pembuatan ekstrak bawang putih.

\section{Pendahuluan}

Susu merupakan bahan makanan berasal dari ternak yang memiliki nilai gizi tinggi seperti protein, mineral, kalori, dan hampir semua zat yang dibutuhkan oleh manusia terdapat dalam susu. Zat ini sangat mudah dicerna dan diserap oleh darah dengan sempurna. Susunan zat gizi dari susu ini merupakan media yang baik untuk pertumbuhan mikroba. Keberadaan mikroba di dalam susu, mengakibatkan kerusakan pada susu. Cemaran mikroba pada susu dapa berasal dari pekerja, lingkungan sekitar kandang, peralatan kandang yang tidak higienis, dan berasal dari mikroba yang terdapat di sekitar ambing. Penyebaran mikroba disekitar ambing akan dapat menyebabkan penyakit mastitis (radang ambing) ternak sapi. Mastitis merupakan peradangan jaringan internal padsa ambing. California Mastitis Test.California mastitis test (CMT), merupakan satu-satunya metoda uji untuk deteksi mastitis subklinis yang selama in digunakan. California Mastitis Test (CMT) merupakan salah satu metode diagnosa mastitis subklinis yang sampai saat ini dianggap sederhana dan cepa yaitu metode dengan menggunakan alat yang disebut paddle dan menggunakan reagen IPB-1 untuk mengetahui tingkat keparahan mastitis subklinis yang dialami (Pradiee et al., 2012). Penyakit tersebut sangat merugikan pendapatan dalam suatu usaha peternakan sapi perah karena produksi susu akan berkurang dan kualitas susu menurun.

Penanganan ini dapat dilakukan dengan pengobatan dan pencegahan Pengobatan dapat dilakukan dengan menggunakan antibiotik sesuai dengan bakteri yang menginfeksi dan disarankan agar dilakukan uji sensitivitas terhadap bakteri sebelum melakukan pengobatan agar diperoleh hasil yang optimal. Pencegahan perlu diperhatikan higiene dan manajemen pemerahan serta sanitasi kandang. Salah satu usaha yang dilakukan untuk mencegah penyakit mastitis pada ambing adalah celup puting. Celup puting dapa dilakukan dengan desinfektan maupun bahan alami lainnya yang dapa membunuh bakteri penyebab mastitis. Dalam penelitian ini dilakukan pencelupan puting menggunakan ekstrak bawang putih (Allium sativum) Menurut penelitian Puspitasari (2008), bawang putih (Allium sativum) sanga mudah diperoleh di seluruh Indonesia, selain itu bawang putih (Allium sativum) merupakan salah satu bumbu dapur yang sangat lazim digunakan di dalam masakan. Kandungan khas yang terdapat di dalam bawang putih (Allium sativum) ialah sejenis minyak astiri dengan bau khas bawang putih (Allium sativum) yang diberi nama Allicin. Allicin memiliki kandungan senyawa aktif yang diduga mempunyai daya bakteriostatik. Dengan adanya daya bakteriostatik maka bawang putih (Allium sativum) digunakan sebagai bahan alami celup puting untuk pencegahan cemaran mikroba pada susu.

\section{Metode}

Penelitian ini dilaksanakan selama satu bulan di Peternakan Sapi Perah Novisiat Claretian Desa Benlutu, Kecamatan Batu Putih dalam wilayah Kabupaten Timor Tengah Selatan dan dilanjutkan uji di Laboratorium Biolog Universitas Katolik Widya Mandira Kupang. Metode penelitian in menggunakan Rancangan Acak Lengkap (RAL) dengan konsentrasi ekstrak bawang putih yaitu $20 \%, 25 \%, 30 \%$ dan antisep komersial sebagai kontro dengan pengulangan sebanyak 3 kali. Variabel yang diamati dalam penelitian ini adalah waktu reduktase dan total bakteri. Analisis data yang digunakan dalam penelitian ini adalah sidik ragam sesuai Rancangan Acak Lengkap (RAL). Apabila berpengaruh nyata akan dinyatakan analisis lanjut dengan menggunakan Uji Jarak Berganda Duncan (Steel dan Torrie, 1991)

\section{Hasil dan Pembahasan \\ 3.1 Waktu Reduktase}

Susu merupakan media pertumbuhan yang tepat untuk mikroba karena mengandung bahan organik untuk pertumbuhannya. Semakin banyak bakter yang ada di dalam susu, menyebabkan susu mudah rusak. Kerusakan pada susu dapat diketahui dengan pengujian secara mikrobiologi. Salah satu pengujian mikrobiologi susu adalah Methylene Blue Reduction Test (MBRT).

Uji ini dapat memberikan perkiraan jumlah bakteri dalam susu dengan mengamati waktu yang dibutuhkan oleh bakteri untuk melakukan aktivitas yang dapat menyebabkan perubahan zat warna biru metilen. Semakin tinggi jumlah bakteri yang terdapat dalam susu, semakin cepat waktu yang diperlukan untuk merubah warna biru metilen pada susu menjadi warna putih. Hal in sesuai dengan Standar Nasional Indonesia (1998), uji reduktase digunakan untuk menentukan kualitas susu dan salah satu cara untuk mengetahui jumlah bakteri di dalam susu secara tidak langsung. Dalam uji ini ditambahkan sejumlah methilen blue ke dalam susu, kemudian diamati kemampuan bakteri di dalam susu untuk tumbuh dalam menggunakan oksigen terlarut, sehingga menurunkan kekuatan oksidasi-reduksi dari campuran tersebut yang menyebabkan methilen blue yang ditambahkan akan tereduksi menjadi putih.

Hasil analisis statistik menunjukkan hasil yang tidak signifikan antara larutan ekstrak bawang putih dan larutan antisep komersial. Hal in menunjukkan bahwa ekstrak bawang putih dan larutan komersial memiliki kemampuan yang sama dalam menghambat bakteri. Ekstrak bawang putih mengandung senyawa antibakteri allicin yang dapat menghambat pertumbuhan bakteri dalam susu sesuai dengan pendapat Eja et al. (2007)allicin bereaksi menghambat sintesis RNA dan sebagian menghambat DNA bakteri dan sintesa protein dimana RNA merupakan target utama dari allicin. Ketentuan penerimaan atau penolakan susu segar berdasarkan Uji MBRT terlihat pada Tabel 1

Tabel 1. Ketentuan Penerimaan atau Penolakan Susu Segar Berdasarkan Uji MBRT

\begin{tabular}{cccc}
\hline No. & Waktu & Total Bakteri & Kesimpulan \\
\hline 1. & $>8$ jam & $<500 \mathrm{rb} / \mathrm{ml}$ & Terima \\
2. & $4-6$ jam & $2-4 \mathrm{jt} / \mathrm{ml}$ & Terima \\
3. & $2-4$ jam & $4-6 \mathrm{jt} / \mathrm{ml}$ & Terima \\
4. & $1-2 \mathrm{jam}$ & $6-8 \mathrm{jt} / \mathrm{ml}$ & Tolak \\
5. & $<1 \mathrm{jam}$ & $>8 \mathrm{jt} / \mathrm{ml}$ & Tolak \\
\hline
\end{tabular}

Sumber : Dept. R\&D dan QC CV. Cita Nasional, 2013.

\subsection{Total Bakteri}

Susu merupakan media yang baik untuk pertumbuhan mikroba, baik mikroba yang menguntungkan maupun merugikan. Jumlah bakteri dalam susu dapat digunakan sebagai indikator pencemaran dan kualitas susu. Dari hal tersebut maka pemeriksaan secara biologis perlu dilakukan pada susu sapi segar. Cara uji secara biologis untuk mengetahui jumlah bakteri pada susu adalah dengan uji Total Plate Count (TPC). Metode TPC mempunyai prinsip menumbuhkan bakteri yang ada di dalam susu dengan media agar sehingga bakteri dapat terlihat dan dapat dihitung jumlahnya.

Hasil analisis statistik menunjukkan hasil yang tidak berbeda nyata yang berarti kemampuan bawang putih setara dengan kemampuan larutan celup puting komersial. Hal ini menunjukkan bahwa bawang putih mampu digunakan sebagai pengganti celup puting komersial. Total bakteri yang terdapat dalam susu diambil di Peternakan Novisiat Claretian Benlutu masih dalam keadaan normal. Menurut SNI (2011), susu yang baik memiliki jumlah cemaran mikroba maksimum sebanyak $1.000 .000 \mathrm{cfu} / \mathrm{mL}$. 
Keberagaman dalam hasil Total Plate Count susu sapi segar disebabkan perbedaan dalam sanitasi peralatan, kandang dan pemerahan. Total Plate Count yang didapat disebabkan oleh daerah buangan feses yang masih berdekatan dengan kandang, sehingga ketika dilakukan pemerahan mikroorganisme dapat masuk melalui debu yang dibawa oleh angin. Peralatan dapat menjadi sumber kontaminasi apabila tidak dibersihkan secara maksimal terutama bagian yang kontak langsung dengan susu. Proses pencemaran mikroba pada susu dimulai ketika susu diperah karena adanya mikroba yang tumbuh disekitar ambing, sehingga saat pemerahan bakteri tersebut terbawa dengan susu (Cahyono et al., 2013). Proses pemerahan di Peternakan Claretian Benlutu juga masih menggunakan sistem pemerahan manual menggunakan tangan sehingga belum begitu higienis. Sesuai dengan Surjowardojo et al. (2008) menyatakan bahwa pengaruh lingkungan, kualitas pakan yang rendah, ketersediaan nutrisi yang rendah, dan kesehatan ternak sangat mempengaruhi produksi susu.

Dalam penelitian ini ekstrak bawang putih sebagai bahan alami pengganti antisep komersial. Bawang putih memiliki beberapa kandungan yang berperan aktif dalam menghambat pertumbuhan dan membunuh bakteri. Kandungan tersebut diantara lain ialah Allicin, minyak astiri, Ajoene dan juga Flavonoid, yang secara sinergis bekerja sama dalam menghasilkan aktivitas antibakteri bawang putih. Cara kerja Allicin dalam menghambat pertumbuhan bakteri ialah dengan cara menghambat secara total sintesis RNA bakteri. Walaupun sintesis DNA dan protein juga mengalami penghambatan sebagian oleh Allicin, nampaknya RNA bakteri merupakan target utama Allicin (Deresse, 2010). Bawang putih juga mengandung komponen minyak atsiri, yang juga memiliki aktivitas anti bakteri yang bekerja dengan mekanisme menghambat pembentukan membran sel bakteri. Namun, potensi minyak atsiri sebagai anti jamur dikenal jauh lebih besar dibanding potensinya sebagai antibakteri (Benkeblia, 2004). Ajoene membantu menghambat sintesis RNA dan DNA bakteri secara lambat. Flavonoid bekerja dengan cara mendenaturasi protein yang dimiliki bakteri. Senyawa flavonoid ini juga dikenal baik sebagai antioksidan. Flavonoid merupakan turunan senyawa fenol yang dapat berinteraksi dengan sel bakteri dengan cara adsorpsi yang dalam prosesnya melibatkan ikatan hidrogen. Dalam kadar yang rendah, fenol membentuk kompleks protein dengan ikatan lemah. Yang akan segera terurai dan diikuti oleh penetrasi fenol ke dalam sel, dan menyebabkan presipitasi dan denaturasi protein (Gulfraz, 2014). Selain itu pula, fenol dapat menghambat aktivitas enzim bakteri, yang pada akhirnya akan mengganggumetabolisme serta proses kelangsungan hidup bakteri tersebut (Basjir, 2012).

Hasil uji MBRT dan TPC menunjukkan hasil yang sama yaitu larutan ekstrak bawang putih tidak signifikan dengan larutan antisep komersial. Perlakuan celup puting dengan konsentrasi larutan ekstrak bawang putih $20 \%$, $25 \%$ dan $30 \%$ memiliki kemampuan yang sama dalam menghambat bakteri. Hal ini dapat dinyatakan bahwa ekstrak bawang putih dengan konsentrasi $20 \%$ sudah cukup untuk digunakan dalam proses celup puting pada sapi perah karena selain memiliki kemampuan yang sama dalam menghambat pertumbuhan bakteri pada susu juga dapat menghemat penggunaan larutan ekstrak bawang putih.

\section{Simpulan}

Kualitas susu di peternakan Claretian Benlutu masih dikategorikan berkualitas baik. Hal ini dapat dilihat dari hasil uji Methylen Blue Reduction Test bahwa perubahan warna biru methilen masih melewati standar yaitu $4-6$ jam dan uji Total Plate Count bahwa jumlah total bakteri dalam susu masih $<1$ $\mathrm{x} 10^{6}$. Hasil uji mikrobiologis dari 2 variabel susu penggunaan ekstrak bawang putih dengan konsentrasi $20 \%$ sudah sangat optimal dalam penggunaan celup puting susu sapi perah selain menghambat bakteri juga menghemat biaya dalam pembuatan ekstrak bawang putih. Penggunaan ekstrak bawang putih dalam proses pencelupan puting di peternakan Claretian Benlutu berpengaruh sangat baik untuk pencegahan mastitis pada ternak sapi perah karena memmiliki efek yang sama dengan larutan antisep komersial. Hal ini berarti ekstrak bawang putih dapat dijadikan sebagai bahan alami pencelupan puting susu sapi.

\section{Pustaka}

Basjir, Erlinda T, Nikham. 2012. Uji Bahan Baku Antibakteri Dari Buah Mahkota Dewa (Phaleria macrocarpa (Scheff) Boerl.) Hasil Radiasi Gamma dan Antibiotik Terhadap Bakteri Patogen. Prosiding Pertemuan Ilmiah Ilmu Pengetahuan dan Teknologi Bahan; 168-174. ISSN 1411$2213 ; 2012$.

Benkeblia N. 2004. Antimicrobial activity of essential oil extracts of various onions (Allium cepa) and garlic (Allium sativum). Lebensm.-Wiss. u.Technol. 37: 263-268.

Cahyono, D., M. C. Padaga dan M. E. Sawitri. 2013. Kajian Kualitas Mikrobiologis (Total Plate Count (TPC), Entero bacteriaceae dan Staphylococcus aureus) Susu Sapi Segar di Kecamatan Krucil Kabupaten Probolinggo. Jurnal Ilmu dan Teknologi Hasil Ternak 8 (1): $1-8$.

Deresse, D. 2010. Antibacterial Effect Of Garlic (Allium sativum) On Staphylococcus Aureus: An in vitro Study. Asian Journal of Medical Science. 2 (2): $62-65$.

Eja, M. E., B. E. Asikong, C. Abriba, G. E. Arikpo, E. E Anwan and K. H. Enyi-Idoh. 2007. A comparative assessment of the antimicrobial effects of garlic (Allium Sativum) and antibiotics on diarrheagenic organisms. Southeast Asian J. Trop Med Public Health. 38: 343-348.
Gulfraz M, Imran M, Khadam S, Ahmed D, Asad MJ, Abassi KS, Irfan M, Mehmood S. 2014. A comparative study of antimicrobial and antioxidant activities of garlic (Allium sativum L.) extracts in various localities of Pakistan. Afr J Plant Sci 8: 298-306. DOI: 10.5897/AJPS11.252.

Pradiee, J., C.R. Moraes., M. Goncalves., M.S. Vilanova., G.F. Correa., O.G. Laus., M.T.M. Osoria and V. Schmidt. 2012. Somatic Cell Count and Californi Mastitis Test as a Diagnostic Tool for Subclinical Mastitis in Ewes. Acta Scientiae Veterinariae, 40 (2): 1-7.

Puspitasari, I. 2008. Uji aktivitas Antibakteri Ekstrak Bawang Putih (Allium Sativum Linn) Terhadap Bakteri Staphylococcus Aureus In vitro. Skripsi. Semarang: Fakultas Kedokteran Universitas Diponegoro.

Standarisasi Nasional Indonesia (SNI). 1998. Standarisasi Susu Segar. Badan Standarisasi Nasional (BSN), Jakarta

Standarisasi Nasional Indonesia (SNI). 2011. 3141.1:2011. Susu Segar. Badan Standarisasi Nasional. Jakarta.

Steel, R.C \& Torrie J. H. 1991. Prinsip dan Prosedur Statistika, Edisi Kedua. PT.Gramedia. Jakarta.

Surjowardojo P, Suryadi, Hakim L, Aulani. 2008. Ekspresi produksi susu pada sapi perah mastitis. J Ternak Tropika. 9(2):1-11. 